\title{
PRINCIPALS OF FINANCIAL MODELLING
}

\author{
Sławomir JANISZEWSKI \\ Faculty of Management \\ Warsaw University of Technology, Warsaw, Poland \\ email: slawomir.janiszewski@pl.pwc.com
}

\begin{abstract}
The financial statements submitted by each company annually reflect their financial performance in the past but are also utilized to forecast the future results in quantitative and realistic frames. The aim of the following elaboration is to thoroughly research all the issues related to financial modelling. The author step by step introduces the reader with theoretical and practical assumptions related to forecasting of respectively, the profit \& loss account, balance sheet account and cash flow statement. All of the issues are illustrated with excel spreadsheets that were prepared exclusively for this article purposes.
\end{abstract}

Key words: financial model, input module, output module, calculation module, profit \& loss account, balance sheet, cash flow statement.

1

\section{Introduction}

The main objective of preparing a financial model is to reflect the forecasted financial performance of the company. The main areas of utilisation the financial model are as follows:

- compilation of financial projections for the company being valued using Discounted Cash Flow (DCF) approach,

- compilation of financial projections for the company (no valuation involved).

The above mentioned are just the two general (indirect) areas of model utilisation. The direct objectives might vary depending on the company needs and might include e.g. profitability analysis, cost analysis, sensitivity analysis and impairment tests [13].
It is however important to analyse the objective of preparing the financial model before the analytical work begins. The financial model of a company prepared for valuation purposes shall differ from the one prepared for cost analysis purposes as an example.

The types of the financial models might be split with respect to two main criteria: consolidated/standalone basis or valuation approach being used (see Table 1).

Other approaches include primarily usage of the financial models for e.g. leverage buy-out analysis, synergy effect analysis and other specific analysis.

Before the assumptions concerning key inputs are plugged into the financial model the thorough analysis and reconciliation of historical performance of the valued entity must be performed. The history reconciliation is performed for both balance sheet and profit and loss account, but excluding cash - flow statement.

Table 1. Possible applications of different types of valuation models based on types of financial statements (source: self study)

\begin{tabular}{|l|c|c|c|c|}
\hline & $\begin{array}{c}\text { Free Cash Flow } \\
\text { to Equity }\end{array}$ & $\begin{array}{c}\text { Free Cash Flow } \\
\text { to Firm }\end{array}$ & $\begin{array}{c}\text { Dividend } \\
\text { Discount Valuation }\end{array}$ & $\begin{array}{c}\text { Other } \\
\text { approaches }\end{array}$ \\
\hline Standalone basis & $\sqrt{ }$ & $\sqrt{ }$ & $\sqrt{ }$ & $\sqrt{ }$ \\
\hline $\begin{array}{l}\text { Consolidated } \\
\text { basis }\end{array}$ & $\sqrt{ }$ & $\sqrt{ }$ & $\sqrt{ }$ \\
\hline
\end{tabular}




\begin{tabular}{|c|c|c|c|c|c|c|c|c|}
\hline & Unit & 2003 & 2004 & 2005 & 2006 & 2007 & 2008 & 2009 \\
\hline \multicolumn{9}{|l|}{ Poland } \\
\hline Inflation rate (December to December) & [\%] & $1.10 \%$ & $2.00 \%$ & $2.00 \%$ & $19.00 \%$ & $19.00 \%$ & $19.00 \%$ & $19.00 \%$ \\
\hline Average inflation & [\%] & $2.30 \%$ & $1.55 \%$ & $2.00 \%$ & $10.50 \%$ & $19.00 \%$ & $19.00 \%$ & $19.00 \%$ \\
\hline Nominal corporate income tax rate & {$[\%]$} & $27.0 \%$ & $19.0 \%$ & $19.0 \%$ & $19.0 \%$ & $19.0 \%$ & $19.0 \%$ & $19.0 \%$ \\
\hline \multicolumn{9}{|l|}{$\mathrm{F} / \mathrm{X}$} \\
\hline F/X rate PLN/EUR at the end of the period & PLN/EUR & 4.00 & 4.00 & 4.01 & 4.69 & 5.49 & 6.43 & 7.52 \\
\hline Average $\mathrm{F} / \mathrm{X}$ rate $\mathrm{PLN} / \mathrm{EUR}$ in the period & PLN/EUR & 4.00 & 4.00 & 4.01 & 4.35 & 5.09 & 5.96 & 6.97 \\
\hline \multicolumn{9}{|l|}{ Interest rate } \\
\hline 3 month WIBOR & [\%] & $9.1 \%$ & $6.3 \%$ & $5.7 \%$ & $4.7 \%$ & $4.6 \%$ & $4.6 \%$ & $4.6 \%$ \\
\hline Bank rate for deposits & [\%] & $6.9 \%$ & $4.8 \%$ & $4.2 \%$ & $3.2 \%$ & $3.1 \%$ & $3.1 \%$ & $3.5 \%$ \\
\hline 52-week Treasury Bills & {$[\%]$} & $8.4 \%$ & $5.9 \%$ & $5.2 \%$ & $4.3 \%$ & $4.1 \%$ & $4.1 \%$ & $4.1 \%$ \\
\hline
\end{tabular}

Figure 1. Macroeconomic assumptions

(source: self study)

It is crucial that the breakdown of all profit and loss (revenues, costs) and balance sheet captions for the historical period is identical to the one of forecasted period. Therefore before the history reconciliation is performed the general structure of the financial model, the key-drivers and information-flow shall be identified. Items that affect the company's performance and which may be the subject of sensitivity analysis should be broken out, while other items might be presented on aggregated basis $[6,3]$.

While performing the historical data reconciliation it is always recommended to compare the company's past performance with forecasted by the management future results of the company. Generally past performance can be a good indicator of future performance. Therefore, any significant changes in financial performance (e. g, EBIT margins increases, sales volume or price increases) shall be verified on case-by-case basis. This is often called the 'hockey stick' effect, and can undermine the credibility of the projections [8]. A very effective means of checking the model can be to study the year-to-year performance of the company and look for dramatic or unexplained shifts in performance

The general principles how to structure financial model are presented below:

- the financial model should have a modular structure and should be consist of thee main modules:

- input module,

- calculation module,

- output module,
- the financial model should be flexible, permitting to extend financial projections period; Moreover financial model should be structured to allow testing of a variety of assumptions,

- the model should adhere as rigorously as possible to accounting fundamentals; on the other hand some reclassifications and aggregative approaches that do not have material impact on the valuation results are possible e.g. division of fixed assets into 4 main categories and estimating average depreciation rate for each of the category,

- the financial model should not be more complex than the requirements of the analytical problem it is designed for.

\section{Input module}

Input module consists usually of three different spreadsheets:

- Macroeconomic assumptions

The data plugged on this spreadsheet include all the factors that refer to the forecasted performance of the economy that might affect either the performance of the valued company or the valuation specific parameters e.g. discount rates. Therefore macroeconomic assumptions might be usually split into three categories: market specific factors (market growth, saturation); GDP and inflation; Interest rates (T-Bills, WIBOR, LIBOR, deposit rates). 


\begin{tabular}{|c|c|c|c|c|c|c|c|}
\hline & Unit & 2004 & 2005 & 2006 & 2007 & 2008 & 2009 \\
\hline \multicolumn{8}{|c|}{ Increase of total number of cards embos sed } \\
\hline Company & {$[\%]$} & $1.0 \%$ & $2.0 \%$ & $2.0 \%$ & $2.0 \%$ & $0.0 \%$ & $0.0 \%$ \\
\hline Bank A & {$[\%]$} & $1.0 \%$ & $2.0 \%$ & $1.0 \%$ & $1.0 \%$ & $0.0 \%$ & $0.0 \%$ \\
\hline Bank B & {$[\%]$} & $1.0 \%$ & $2.0 \%$ & $1.0 \%$ & $1.0 \%$ & $0.0 \%$ & $0.0 \%$ \\
\hline \multicolumn{8}{|c|}{ Structure of the cards emboss ed } \\
\hline Debit cards & {$[\%]$} & $40.0 \%$ & $40.0 \%$ & $40.0 \%$ & $40.0 \%$ & $40.0 \%$ & $40.0 \%$ \\
\hline Credit cards & {$[\%]$} & $60.0 \%$ & $60.0 \%$ & $60.0 \%$ & $60.0 \%$ & $60.0 \%$ & $60.0 \%$ \\
\hline \multicolumn{8}{|c|}{ Total transactions per card } \\
\hline Company & [number] & 100 & 100 & 100 & 100 & 100 & 100 \\
\hline Bank A & [number] & 110 & 110 & 110 & 110 & 110 & 110 \\
\hline Bank B & [number] & 120 & 120 & 120 & 120 & 120 & 120 \\
\hline
\end{tabular}

\begin{tabular}{|c|c|c|c|c|c|c|c|}
\hline \multicolumn{8}{|l|}{ Cardholder management } \\
\hline Bank A debit cards & {$[\%]$} & $20 \%$ & $20 \%$ & $20 \%$ & $20 \%$ & $20 \%$ & $20 \%$ \\
\hline Bank B debit cards & {$[\%]$} & $20 \%$ & $20 \%$ & $20 \%$ & $20 \%$ & $20 \%$ & $20 \%$ \\
\hline Bank A credit cards & {$[\%]$} & $20 \%$ & $20 \%$ & $20 \%$ & $20 \%$ & $20 \%$ & $20 \%$ \\
\hline Bank B credit cards & {$[\%]$} & $20 \%$ & $20 \%$ & $20 \%$ & $20 \%$ & $20 \%$ & $20 \%$ \\
\hline \multicolumn{8}{|l|}{ Cards trans actions } \\
\hline Bank A catrd transations & {$[\%]$} & $20 \%$ & $20 \%$ & $20 \%$ & $20 \%$ & $20 \%$ & $20 \%$ \\
\hline Bank B catrd transations & {$[\%]$} & $20 \%$ & $20 \%$ & $20 \%$ & $20 \%$ & $20 \%$ & $20 \%$ \\
\hline CAPITAL EXPENDITURES & ['000 PLN] & 810 & 1210 & 1210 & 1210 & 1210 & 1210 \\
\hline Intangibles & ['000 PLN] & 400 & 600 & 600 & 600 & 600 & 600 \\
\hline Land & ['O00 PLN] & 200 & 200 & 200 & 200 & 200 & 200 \\
\hline Buildings and constructions & ['O00 PLN] & 200 & 400 & 400 & 400 & 400 & 400 \\
\hline Other fixed assets & ['O00 PLN] & 10 & 10 & 10 & 10 & 10 & 10 \\
\hline \multicolumn{8}{|l|}{ WORKING CAPITAL TURNOVER } \\
\hline Trade receivables - dometic & ['000 PLN] & 30 & 30 & 30 & 30 & 30 & 30 \\
\hline Trade receivables - export & ['000 PLN] & 45 & 45 & 45 & 45 & 45 & 45 \\
\hline Trade payables - domestic & ['O00 PLN] & 30 & 30 & 30 & 30 & 30 & 30 \\
\hline Trade payables - export & ['O00 PLN] & 45 & 45 & 45 & 45 & 45 & 45 \\
\hline Inventory & ['000 PLN] & 10 & 10 & 10 & 10 & 10 & 10 \\
\hline
\end{tabular}

Figure 2. Operating assumptions (source: self study)

In case of the financial projections in current prices, all the profit and loss captions shall be adjusted for the year-average inflation and balance sheet captions shall be adjusted for December - December inflation, it is recommended to presented the both inflation ratio on the spreadsheet with macroeconomic assumptions [1].

The exemplary screenshot of spreadsheet with macroeconomic assumptions is presented in Fig. 1.

\section{- Operating assumptions}

The data plugged on this spreadsheet include all the factors that refer to the forecasted performance of the company. The structure and complexity of the operating assumptions shall be considered on case-bycase and might vary significantly with respect to different projects. In general operating assumptions might be split into five vogue categories: sales as- sumptions (volume increases, real price increases); operating costs assumptions (margins, unit costs of materials); capital expenditures, working capital (turnover of receivables, payables, inventory and operating cash); other assumptions (dividend payout ratio, provision for receivables) [11].

The exemplary screenshot of spreadsheet with operating assumptions is presented in Fig. 2.

\section{- KVD spreadsheet}

The data presented on this spreadsheet include primarily the results and the key drivers of the sensitivity analysis. The structure and complexity of KVD shall be considered on case-by-case and might vary significantly with respect to different projects.

The exemplary screenshot of KVD spreadsheet is presented in Fig. 3. 
Ilustrative Valuation of ABC Company as of 31 December 2002 KVD - Sensitivity Analysis

\begin{tabular}{lcccccc}
\hline & & $\mathbf{2 0 0 4}$ & $\mathbf{2 0 0 5}$ & $\mathbf{2 0 0 6}$ & $\mathbf{2 0 0 7}$ & $\mathbf{2 0 0 8}$ \\
\hline Change in contract revenues & {$[\%]$} & $0.0 \%$ & $0.0 \%$ & $0.0 \%$ & $0.0 \%$ & $0.0 \%$ \\
Change in non-contract revenues & {$[\%]$} & $0.0 \%$ & $0.0 \%$ & $0.0 \%$ & $0.0 \%$ & $0.0 \%$ \\
Change in costs of external services & {$[\%]$} & $0.0 \%$ & $0.0 \%$ & $0.0 \%$ & $0.0 \%$ & $0.0 \%$ \\
Change in Other costs - other & {$[\%]$} & $0.0 \%$ & $0.0 \%$ & $0.0 \%$ & $0.0 \%$ & $0.0 \%$ \\
Change in cost of equity & $0.0 \%$ & & & & &
\end{tabular}

Change in cost of equity

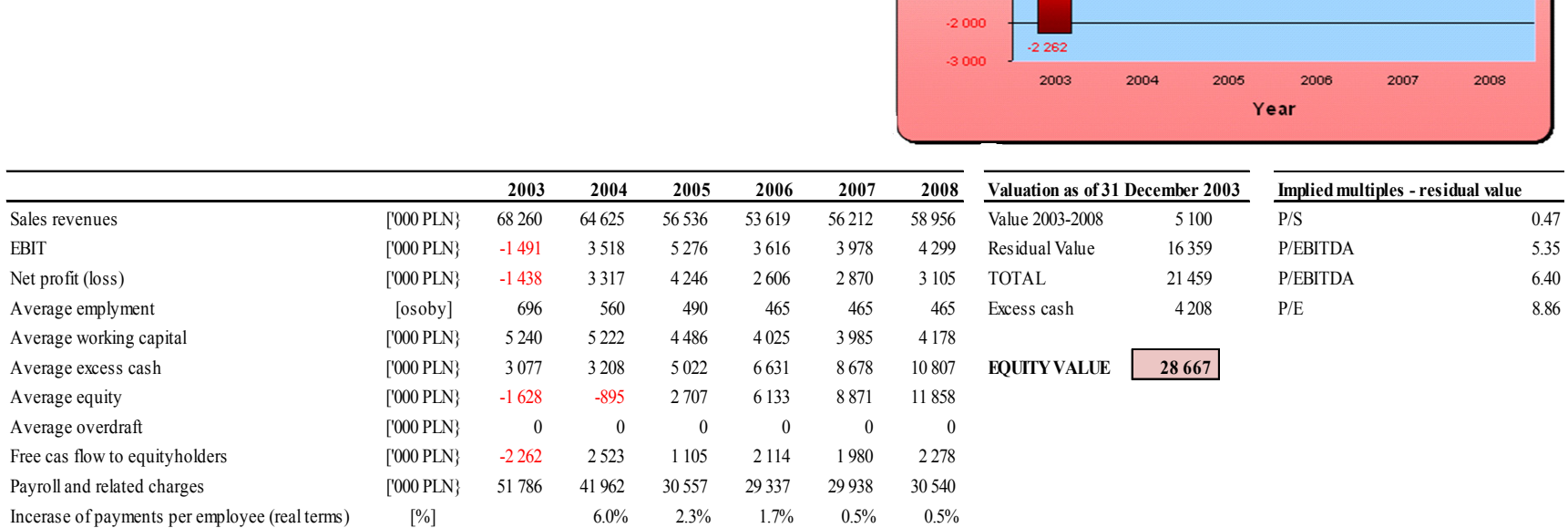

Figure 3. Exemplary screenshot of KVD (source: self study)

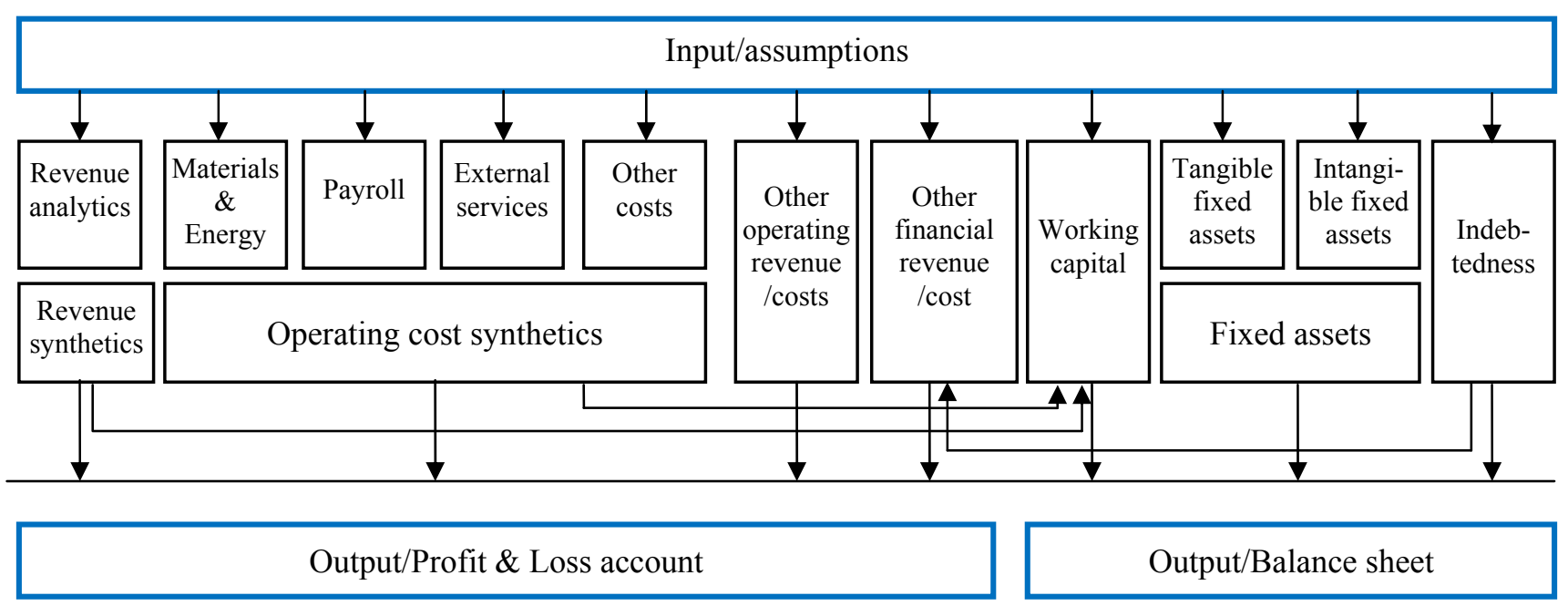

Figure 4. The exemplary structure of the calculation module included in the financial model (source: self study)

\section{Calculation module}

The number of the spreadsheets in the calculation module depends on the business specific factors and shall be considered on project-by-projects basis. The exemplary structure of the calculation module included in the financial model of a commercial company is presented in Fig. 4.

In case particular areas are subject to simplified approach these might be calculated on one spreadsheet e.g. fixed assets. On the other hand, if particular areas require thorough analysis, these might be modelled using several spreadsheets e.g. cost of materials and energy or production process flow. The general rule governing all financial models shall be the hierarchical data flow: input - calculation - output.

- Analytics vs. synthetics

The most common approach is to present the aggregated data on the top of the spreadsheet (see Fig. 5) if only possible. The detailed calculation presented in the bottom of the spreadsheet shall be followed by the aggregated data. 
llus trative Valuation of ABC Company as of 31 December 2003 Sales of products and services

\begin{tabular}{|c|c|c|c|c|c|c|c|}
\hline & Unit & 2003 & 2004 & 2005 & 2006 & $\mathbf{2 0 0 7}$ & 2008 \\
\hline Sales reve nue & '000 PLN] & 40914 & 44062 & 47474 & 51101 & 54819 & 56381 \\
\hline Product 1 & ['OOO PLN] & 19258 & 20740 & 22346 & 24053 & 25803 & 26539 \\
\hline Product 2 & ['OOO PLN] & 12582 & 13549 & 14599 & 15714 & 16857 & 17338 \\
\hline Product 3 & ['000 PLN] & 9074 & 9772 & 10529 & 11334 & 12158 & 12505 \\
\hline Product 1 & O00 PLN] & 19258 & 20740 & 22346 & 24053 & 25803 & 26539 \\
\hline Retail & ['OOO PLN] & 4622 & 4355 & 4469 & 4570 & 5419 & 5573 \\
\hline Wholesale & ['O00 PLN] & 11555 & 12444 & 12961 & 13229 & 13160 & 13004 \\
\hline Distribution network & ['O00 PLN] & 1926 & 2489 & 3128 & 4089 & 4903 & 5308 \\
\hline $\mathrm{B} 2 \mathrm{~B}$ & ['O00 PLN] & 1156 & 1452 & 1788 & 2165 & 2322 & 2654 \\
\hline Product 2 & '000 PLN] & 12582 & 13549 & 14599 & 15714 & 16857 & 17338 \\
\hline Retail & ['OOO PLN] & 2642 & 2710 & 2920 & 3143 & 3709 & 3814 \\
\hline Wholesale & ['OOO PLN] & 6920 & 7452 & 7883 & 8328 & 8429 & 8669 \\
\hline Distribution network & ['OOO PLN] & 629 & 813 & 1022 & 1257 & 1686 & 1907 \\
\hline $\mathrm{B} 2 \mathrm{~B}$ & ['000 PLN] & 2391 & 2574 & 2774 & 2986 & 3034 & 2947 \\
\hline Product 3 & '000 PLN] & 9074 & 9772 & 10529 & 11334 & 12158 & 12505 \\
\hline Retail & ['OOO PLN] & 1815 & 2052 & 1369 & 1700 & 1945 & 2001 \\
\hline Wholesale & ['000 PLN] & 4537 & 5766 & 7370 & 7027 & 6809 & 6502 \\
\hline Distribution network & ['000 PLN] & 635 & 1759 & 1579 & 2380 & 3161 & 3751 \\
\hline $\mathrm{B} 2 \mathrm{~B}$ & ['OOO PLN] & 2087 & 195 & 211 & 227 & 243 & 250 \\
\hline
\end{tabular}

Figure 5. Aggregated data (source: self study)

\section{- Sales revenue}

Sales revenue shall be categorized in order to distinguish between the groups of products/services with different profitability. Profitability is usually determined as contribution, margin or mark-up realised on the product/service group. While working over the analytics of the sales revenue the two objectives shall be followed:

- the number of different groups of products/services shall be minimised,

- the total sum of the variances of groups of products/services shall be minimised [10].

The criteria used in revenue categorisation shall be assessed on project-by-project basis. In valuation practise the two dimensions of revenue seem to be very useful:

- product/service group,

- distribution channel.

- Depreciation and amortisation

Depreciation and amortization shall be calculated on pre-formatted Microsoft Excel spreadsheet with respect to different groups of fixed assets. Valuation practice proves that fixed assets are usually split into four groups: intangibles; building and construction, machinery and equipment and other fixed assets (all remaining tangible fixed assets) [3].

For the purposes of compilation of financial projections the weight average economic depreciation rates estimated for different groups of assets shall always be applied. The estimate of depreciation rate might be performed based on historical financial statements (unless there is no evidence that accounting depreciation rates differ significantly from economic depreciation rates) or using the management assumption concerning the asset utilisation $[12,4]$.

In case there is a significant difference between the accounting and economic depreciation rates the adjustment to the historical depreciation rate is necessary.

\section{$4 \quad$ Output module}

The output module consists usually of several spreadsheets that present the data on the aggregated level. These are the spreadsheets that include the results and the summary of the analyses performed in the financial model. 
Table 2. The basic drivers to profit $\&$ loss captions (source: self study)

\begin{tabular}{|c|c|c|c|c|}
\hline & Driver I & $\begin{array}{c}\text { Driver I } \\
\text { derivatives }\end{array}$ & Driver II & $\begin{array}{c}\text { Driver II } \\
\text { derivatives }\end{array}$ \\
\hline \multirow{4}{*}{$\begin{array}{l}\text { Sales } \\
\text { revenue }\end{array}$} & \multirow{2}{*}{ growth } & inflation & \multirow{2}{*}{ sales revenue } & \multirow{2}{*}{ calculated } \\
\hline & & real growth & & \\
\hline & \multirow{2}{*}{ volume output } & output growth & \multirow{2}{*}{$\begin{array}{l}\text { price of product/ } \\
\text { services }\end{array}$} & inflation \\
\hline & & market share & & real growth \\
\hline \multirow{3}{*}{$\begin{array}{l}\text { Materials } \\
\text { \& Energy }\end{array}$} & assumed $\%$ & & sales revenue & calculated \\
\hline & \multirow{2}{*}{$\begin{array}{l}\text { unit material/ } \\
\text { energy usage }\end{array}$} & $\begin{array}{l}\text { constant } \\
\text { (history) }\end{array}$ & \multirow{2}{*}{$\begin{array}{l}\text { unit price of material/ } \\
\text { energy }\end{array}$} & inflation \\
\hline & & & & real growth \\
\hline \multirow{4}{*}{$\begin{array}{l}\text { External } \\
\text { services }\end{array}$} & assumed \% & & sales revenue & calculated \\
\hline & assumed \% & & operating costs & calculated \\
\hline & assumed \% & & $\begin{array}{l}\text { production output/ } \\
\text { material volume e.g. } \\
\text { transport }\end{array}$ & calculated \\
\hline & assumed $\%$ & & $\begin{array}{l}\text { other parameters e.g. } \\
\text { employment e.g. } \\
\text { subcontractors }\end{array}$ & calculated \\
\hline \multirow{3}{*}{ Payroll } & assumed \% & & sales revenue & calculated \\
\hline & \multirow{2}{*}{$\begin{array}{l}\text { number } \\
\text { of employees }\end{array}$} & increases/decreases & \multirow{2}{*}{ average salary } & inflation \\
\hline & & constant & & real growth \\
\hline Depreciation & $\begin{array}{l}\text { depreciation } \\
\text { rate }-\%\end{array}$ & constant & $\begin{array}{l}\text { gross fixed tangible } \\
\text { assets }\end{array}$ & calculated \\
\hline Amortisation & $\begin{array}{l}\text { amortisation } \\
\text { rate }-\% \\
\end{array}$ & constant & $\begin{array}{l}\text { gross fixed intangible } \\
\text { assets }\end{array}$ & calculated \\
\hline \multirow{2}{*}{$\begin{array}{l}\text { Other } \\
\text { operating } \\
\text { revenue }\end{array}$} & \multirow{2}{*}{ constant } & nil & & \\
\hline & & constant & & \\
\hline \multirow{3}{*}{$\begin{array}{l}\text { Other } \\
\text { operating } \\
\text { cost }\end{array}$} & \multirow{2}{*}{ constant } & nil & & \\
\hline & & constant & & \\
\hline & assumed \% & $\begin{array}{l}\text { provision } \\
\text { for receivables }\end{array}$ & sales revenue & calculated \\
\hline $\begin{array}{l}\text { Financial } \\
\text { revenue }\end{array}$ & $\begin{array}{l}\text { interest rates } \\
\text { on deposits }\end{array}$ & & $\begin{array}{l}\text { average operating } \\
\text { cash (valuation) }\end{array}$ & calculated \\
\hline $\begin{array}{l}\text { Financial } \\
\text { expense }\end{array}$ & $\begin{array}{l}\text { interest rates } \\
\text { on loans }\end{array}$ & & $\begin{array}{l}\text { average indebted- } \\
\text { ness }\end{array}$ & calculated \\
\hline
\end{tabular}


llustrative Valuation of ABC Company as of 31 December 2003

Profit and loss accounts

\begin{tabular}{|c|c|c|c|c|c|c|c|c|}
\hline & Unit & 2003 & 2004 & 2005 & 2006 & 2007 & 2008 & 2009 \\
\hline Sales & ['000 PLN] & 43568 & 47532 & 51207 & 55213 & 59217 & 60901 & 62118 \\
\hline Sales of goods bought for resale & ['000 PLN] & 40914 & 44062 & 47474 & 51101 & 54819 & 56381 & 57508 \\
\hline Sales of services & ['000 PLN] & 2654 & 3470 & 3733 & 4113 & 4398 & 4520 & 4610 \\
\hline Operating expenses & ['000 PLN] & 39409 & 44003 & 47875 & 51981 & 55089 & 56542 & 57673 \\
\hline Cost of goods and materials sold & ['000 PLN] & 26795 & 29821 & 32528 & 35796 & 38249 & 39148 & 39931 \\
\hline Energy and other materials & ['000 PLN] & 659 & 682 & 707 & 731 & 754 & 776 & 791 \\
\hline External services & ['000 PLN] & 4042 & 5647 & 6012 & 6496 & 6884 & 7077 & 7218 \\
\hline Payroll and related charges & ['000 PLN] & 5251 & 5336 & 5478 & 5630 & 6163 & 6484 & 6613 \\
\hline Depreciation \& amortisation & ['O00 PLN] & 1145 & 981 & 845 & 853 & 431 & 409 & 417 \\
\hline Other costs & ['000 PLN] & 1518 & 1537 & 2305 & 2475 & 2608 & 2649 & 2702 \\
\hline Gross profit / (loss) on sales & ['000 PLN] & 4159 & 3529 & 3332 & 3232 & 4127 & 4359 & 4446 \\
\hline as percentage of sales & {$[\%]$} & $9.5 \%$ & $7.4 \%$ & $6.5 \%$ & $5.9 \%$ & $7.0 \%$ & $7.2 \%$ & $7.2 \%$ \\
\hline Other operating revenues & ['000 PLN] & 1033 & 829 & 2744 & 606 & 606 & 606 & 619 \\
\hline Other operating expenses & ['000 PLN] & 973 & 799 & 816 & 835 & 853 & 861 & 878 \\
\hline EBIT & ['000 PLN] & 4220 & 3558 & 5260 & 3004 & 3881 & 4104 & 4186 \\
\hline as percentage of sales & {$[\%]$} & $9.7 \%$ & $7.5 \%$ & $10.3 \%$ & $5.4 \%$ & $6.6 \%$ & $6.7 \%$ & $6.7 \%$ \\
\hline Financial revenues & ['000 PLN] & 787 & 63 & 60 & 58 & 53 & 48 & 49 \\
\hline Financial expenses & ['000 PLN] & 1412 & 2081 & 647 & 567 & 348 & 226 & 231 \\
\hline Profit / (loss) on ordinary activities & ['O00 PLN] & 3595 & 1540 & 4673 & 2495 & 3586 & 3926 & 4005 \\
\hline as percentage of sales & {$[\%]$} & $8.3 \%$ & $3.2 \%$ & $9.1 \%$ & $4.5 \%$ & $6.1 \%$ & $6.4 \%$ & $6.4 \%$ \\
\hline Extraordinary gains & ['000 PLN] & 98 & 0 & 0 & 0 & 0 & 0 & 0 \\
\hline Extraordinary losses & ['000 PLN] & 94 & 0 & 0 & 0 & 0 & 0 & 0 \\
\hline Profit / (loss) before taxation & ['000 PLN] & 3598 & 1540 & 4673 & 2495 & 3586 & 3926 & 4005 \\
\hline as percentage of sales & {$[\%]$} & $8.3 \%$ & $3.2 \%$ & $9.1 \%$ & $4.5 \%$ & $6.1 \%$ & $6.4 \%$ & $6.4 \%$ \\
\hline Taxes & ['O00 PLN] & 1713 & 886 & 1427 & 856 & 1116 & 1194 & 1218 \\
\hline Corporate income tax & {$[$ '000 PLN] } & 1713 & 886 & 1427 & 856 & 1116 & 1194 & 1218 \\
\hline Profit / (loss) after taxation & {$[$ ['000 PLN] } & 1885 & 654 & 3246 & 1639 & 2470 & 2732 & 2786 \\
\hline as percentage of sales & {$[\%]$} & $4.3 \%$ & $1.4 \%$ & $6.3 \%$ & $3.0 \%$ & $4.2 \%$ & $4.5 \%$ & $4.5 \%$ \\
\hline
\end{tabular}

Figure 6 . The exemplary screenshot of spreadsheet presenting profit \& loss accounts (source: self study)

The two main groups of spreadsheets categorised upon its objective might be distinguished for the concern of this document:

- Spreadsheets that present the final results on the aggregated level in the form of financial statements.

These comprise of the spreadsheets such as profit and loss account, balance sheet and cash flow statement.

- Spreadsheets that present the additional measures of financial performance.

These comprise of all the spreadsheets that present the additional results of the analysis performed by the financial model e.g. sales and operating costs analysis or ratio analysis.

Profit and loss account is the financial statements that shall be established at the beginning of the process to construct financial model (the exception to this rule refer to the models of financial institutions e.g. banks, insurance companies).

Profit and loss account seems to be a backbone of the financial model as it determines the company future profitability. The forecasted results of the company performance presented in profit and loss statements (EBIT, EBITDA, net profit) derive the value of the company in greatest part. Many of the balance sheet and cash flow items vary as a function of income statement items such as revenue or costs. The basic drivers to profit \& loss captions are presented in Table 2.

It is important to remember that all the profit and loss captions shall be calculated based on year-average balances e.g. operating cash balance or indebtedness balance and year-average inflation rates [13].

In the majority of financial models, it is the cost drivers' identification that seems to be the most challenging task. The first step in analysing costs shall be categorising them into: fixed costs, semi-variable and variable costs. The further steps shall usually be considered on case-by-case basis.

It is worth noticing that relating all the costs to revenue captions is oversimplification that often causes a significant bias on the valuation results. 
llustrative Valuation of $\mathrm{ABC}$ Company as of 31 December 2003 Balance sheets

\begin{tabular}{|c|c|c|c|c|c|c|c|c|}
\hline & Unit & 2003 & 2004 & 2005 & 2006 & 2007 & 2008 & 2009 \\
\hline Fixed assets & ['000 PLN] & 6291 & 5762 & 5633 & 5080 & 4979 & 4910 & 4959 \\
\hline Intangibles & ['000 PLN] & 256 & 240 & 411 & 317 & 214 & 166 & 168 \\
\hline Tangible assets & ['000 PLN] & 6035 & 5521 & 5222 & 4764 & 4765 & 4744 & 4791 \\
\hline Current assets & ['000 PLN] & 17248 & 13773 & 14909 & 16182 & 17332 & 17799 & 17977 \\
\hline Inventory & ['000 PLN] & 5957 & 4902 & 5347 & 5884 & 6288 & 6435 & 6500 \\
\hline Trade receivables & ['000 PLN] & 10362 & 7992 & 8629 & 9312 & 10017 & 10320 & 10423 \\
\hline Other receivables & ['000 PLN] & 441 & 363 & 363 & 363 & 363 & 363 & 367 \\
\hline Operating cash & ['000 PLN] & 488 & 516 & 569 & 623 & 664 & 680 & 687 \\
\hline Excess cash & ['000 PLN] & $\mathbf{0}$ & $\mathbf{0}$ & $\mathbf{0}$ & $\mathbf{0}$ & 139 & 2704 & $\mathbf{0}$ \\
\hline Total Assets & ['000 PLN] & 23538 & 19535 & 20542 & 21263 & 22450 & 25413 & 22936 \\
\hline Equity & ['000 PLN] & 3826 & 4480 & 7725 & 9365 & 11834 & 14566 & 17352 \\
\hline Subscribed share capital & ['000 PLN] & 3098 & 3098 & 3098 & 3098 & 3098 & 3098 & 3098 \\
\hline Capital reserve & ['000 PLN] & 2237 & 2237 & 2237 & 2237 & 2237 & 2237 & 2237 \\
\hline Accumulated profit / (loss) form previous year & ['000 PLN] & -1803 & -1509 & -855 & 2390 & 4030 & 6499 & 9231 \\
\hline Profit / (loss) after taxation for the current financial year & ['000 PLN] & 294 & 654 & 3246 & 1639 & 2470 & 2732 & 2786 \\
\hline Indebtedness & ['000 PLN] & 4475 & 2642 & 3639 & 1906 & $\mathbf{0}$ & $\mathbf{0}$ & $\mathbf{0}$ \\
\hline Overdraft & ['000 PLN] & 2960 & 2242 & 3639 & 1906 & 0 & 0 & 0 \\
\hline Other debt & ['000 PLN] & 1515 & 400 & 0 & 0 & 0 & 0 & 0 \\
\hline Short term liabilities & ['000 PLN] & 10626 & 8151 & 8811 & 9625 & 10248 & 10479 & 5126 \\
\hline Trande accounts payable & ['000 PLN] & 9422 & 7353 & 8021 & 8826 & 9431 & 9653 & 5126 \\
\hline Other short0term liabilities & ['000 PLN] & 1204 & 798 & 790 & 799 & 817 & 826 & 0 \\
\hline ZFRON & ['000 PLN] & 4611 & 4262 & 368 & 368 & 368 & 368 & 368 \\
\hline Total liabilities & ['000 PLN] & 23538 & 19535 & 20542 & 21263 & 22450 & 25413 & 22936 \\
\hline
\end{tabular}

Figure 7. The exemplary screenshot of spreadsheet presenting balance sheet (source: self study)

Cost accounting is a complex discipline on its own, and in most cases it is unrealistic to expect to model all costs (and their relationship to inventory). It is important to understand the cost structure of the business and make sure that it is appropriately reflected in the base model and in all alternative scenarios.

The exemplary screenshot of spreadsheet presenting profit and loss accounts is presented in Fig. 6.

Balance sheet account is the financial statements that shall be established mainly based on information derived from profit and loss accounts (the exception refers to the models of financial institutions e.g. banks, insurance companies where the balance sheet shall be constructed as the first financial statement).

The basic drivers to the balance sheet captions are presented in the Table 3 .

The exemplary screenshot of spreadsheet presenting balance sheets is presented in Fig. 7.

Every year of the financial projections' period implemented in the financial models period must satisfy the general accounting condition that total assets equal total liability. In other words the balance sheet must always balance.

From financial modelling perspective balancing the balance sheet requires implementing a circular into the financial model. The explanation of this issue is presented in Fig. 8.

The overdraft and excess cash balances with the inflow and outflow of cash during each year of the financial projections period making the balance sheet balance. Changes in overdraft and excess cash make the net interest to fluctuate as the interest expense and interest revenues are affected by the changes of overdraft and excess cash, respectively. The fluctuations in net interest affect the company's net income on annual basis. Net income of the year, stripped of dividends is recorded as retain earnings on the liability side of the balance sheet. Change on the liability side of the balance sheet requires rebalancing the balance sheet again using overdraft and excess cash balances. As profit and loss and balance sheet captions are each other logically dependent the circular links are necessary. 
Table 3. The basic drivers to the balance sheet captions (source: self study)

\begin{tabular}{|c|c|c|c|c|}
\hline & Driver I & $\begin{array}{c}\text { Driver I } \\
\text { derivatives }\end{array}$ & Driver II & $\begin{array}{c}\text { Driver II } \\
\text { derivatives }\end{array}$ \\
\hline Intangible fixed assets & $\begin{array}{c}\text { capital } \\
\text { expenditures }\end{array}$ & assumptions & amortisation & $\begin{array}{l}\text { assumptions/ } \\
\text { constant }\end{array}$ \\
\hline Tangible fixed assets & $\begin{array}{c}\text { capital } \\
\text { expenditures }\end{array}$ & assumptions & depreciation & $\begin{array}{l}\text { assumptions/ } \\
\text { constant }\end{array}$ \\
\hline Inventory & $\begin{array}{l}\text { inventory } \\
\text { turnover ratio }\end{array}$ & assumptions & $\begin{array}{l}\text { selected operating } \\
\text { costs }\end{array}$ & calculated \\
\hline $\begin{array}{l}\text { Trade } \\
\text { receivables }\end{array}$ & $\begin{array}{l}\text { receivables } \\
\text { turnover ratio }\end{array}$ & assumptions & sales revenue & calculated \\
\hline $\begin{array}{l}\text { Trade } \\
\text { payables }\end{array}$ & $\begin{array}{c}\text { payables } \\
\text { turnover ratio }\end{array}$ & assumptions & $\begin{array}{l}\text { selected operating } \\
\text { costs }\end{array}$ & calculated \\
\hline Operating cash & $\begin{array}{c}\text { operating } \\
\text { cash turnover ratio }\end{array}$ & assumptions & sales revenue & calculated \\
\hline Excess cash & balancing figure & & & \\
\hline Overdraft & balancing figure & & & \\
\hline Debt & repayments & assumptions & issuing & assumptions \\
\hline Issued capital & issues & assumptions & buy-backs & assumptions \\
\hline Retained earnings & $\begin{array}{c}\text { dividend } \\
\text { payout ratio }\end{array}$ & assumptions & net profit & calculated \\
\hline
\end{tabular}

\section{Balancing the balance sheet}

\section{Assets}

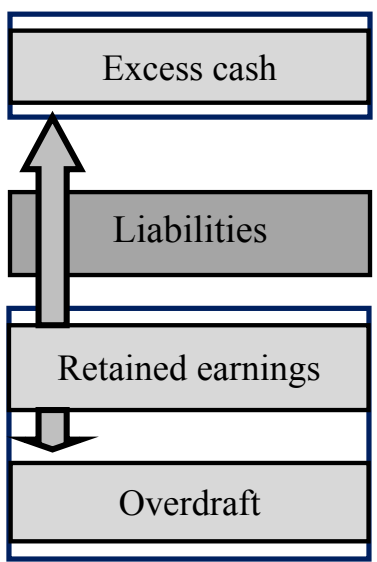

Profit and loss account

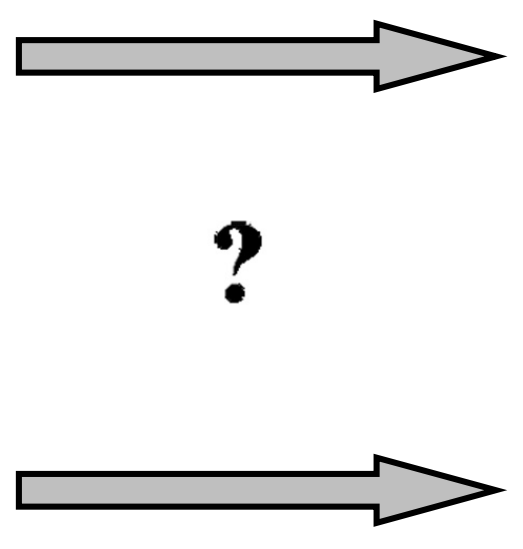

Interest revenue

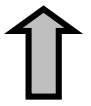

Net profit

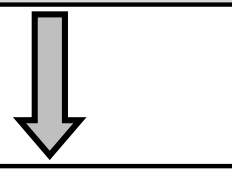

Interest expense

Figure 8. Balancing the balance sheet (source: self study) 
Table 4. The basic drivers to cash flow captions (source: self study)

\begin{tabular}{|c|c|c|c|}
\hline & Status & Source/spreadsheet & $\begin{array}{c}\text { Impact } \\
\text { on cash-flow* } \\
\end{array}$ \\
\hline \multicolumn{4}{|l|}{ Cash from operating activities } \\
\hline Adjusted EBIT & calculated & profit \& loss & positive \\
\hline Corporate Income Tax paid & calculated & profit \& loss/balance sheet & negative \\
\hline Depreciation \& amortisation & calculated & $\begin{array}{c}\text { profit \& loss or fixed assets } \\
\text { (separate) }\end{array}$ & positive \\
\hline Working capital changes & calculated & balance sheet & negative \\
\hline Changes in other assets & calculated & balance sheet & negative \\
\hline Changes in other liabilities & calculated & balance sheet & positive \\
\hline \multicolumn{4}{|l|}{ Cash from investing activities } \\
\hline Capital expenditures & assumption & input or fixed assets (separate) & negative \\
\hline $\begin{array}{l}\text { Proceeds } \\
\text { from sale of fixed assets }\end{array}$ & assumption & input or fixed assets (separate) & positive \\
\hline \multicolumn{4}{|l|}{ Cash from financing activities } \\
\hline Change in indebtedness & calculated & balance sheet or indebtedness & positive \\
\hline Net interest & calculated & profit \& loss & negative \\
\hline Issued capital & calculated & balance sheet & positive \\
\hline
\end{tabular}

* direct impact of the increase of the item on cash-flow statement

The supporting assumptions used while balancing the balance sheet are as follows:

- in case company needs more cash as of the balancing date, it is incurring overdraft - additional short term financing., the company repays as soon as excess cash appears on its balance sheet,

- in case company has excess cash of the balancing date it retains it in the balance sheet (retained earnings); for the valuation purposes the changes in excess cash, adjusted for increases in shareholders capital and dividend payouts are treated as free cash flow to equity/firm.

It is assumed that balancing procedure is recorded in visual basis language using goal seek function implemented. These are implemented for each of the years of the financial projections period [ $[7,14]$.
In extraordinary circumstances, when implementing circular links in the financial model seem inappropriate, there is a possibility to balance the balance sheet on one of the following simplified assumption:

- no interest rate expense/revenue are calculated based on overdraft and excess cash,

- the interest rate expense/revenue are calculated based on the prior year's balances.

In both of these cases circular links are avoided. However, removing circular links increases the risks of calculating inaccurate interest expense/revenue figures if there are wide fluctuations in debt and cash balances.

The more sophisticated approach to balance the balance sheet is applicable while preparing the financial model of a bank. 
llustrative Valuation of ABC Company as of 31 December 2003

Cash flow statements

\begin{tabular}{|c|c|c|c|c|c|c|c|}
\hline & Unit & 2004 & 2005 & 2006 & 2007 & 2008 & 2009 \\
\hline EBIT & ['000 PLN] & $\mathbf{0}$ & 10689 & 28006 & 33510 & 36009 & 35824 \\
\hline Corporate income tax & ['000 PLN] & 0 & -2893 & -7569 & -9056 & -9732 & -9684 \\
\hline Depreciation \& amortisation & ['000 PLN] & 8405 & 6479 & 6479 & 4319 & 0 & 0 \\
\hline Gross cash flow & ['000 PLN] & 8405 & 14274 & 26916 & 28773 & 26277 & 26140 \\
\hline Change in working capital & ['000 PLN] & -4634 & 1897 & -1703 & -430 & 88 & 6 \\
\hline Operating cash & ['000 PLN] & -593 & -88 & -279 & -155 & -62 & -10 \\
\hline Trade receivables & ['000 PLN] & -5926 & -884 & -2794 & -1550 & -620 & -95 \\
\hline Other receivables & ['000 PLN] & 0 & 0 & 0 & 0 & 0 & 0 \\
\hline Other receivables & ['000 PLN] & 1884 & 2869 & 1371 & 1275 & 770 & 111 \\
\hline Change in other assets and liabilities & ['000 PLN] & 332 & 127 & 317 & 61 & -33 & -3 \\
\hline Operating cash flow & ['000 PLN] & 4102 & 16298 & 25531 & 28404 & 26331 & 26143 \\
\hline Capital expenditures & ['000 PLN] & 0 & 0 & 0 & 0 & 0 & 0 \\
\hline Cash flow bwfore financing & ['000 PLN] & 4102 & 16298 & 25531 & 28404 & 26331 & 26143 \\
\hline Financing & ['000 PLN] & $\mathbf{0}$ & 27 & 26 & 32 & 36 & 41 \\
\hline Change in indebtedness & ['000 PLN] & 0 & 0 & 0 & 0 & 0 & 0 \\
\hline Net interest & ['000 PLN] & 0 & 27 & 26 & 32 & 36 & 41 \\
\hline Free cash flow to equityholders & ['000 PLN] & 4102 & 16325 & 25557 & 28436 & 26367 & 26184 \\
\hline Changes in subscribed share capital & ['000 PLN] & 0 & 0 & 0 & 0 & 0 & 0 \\
\hline Changes in excess cash & ['000 PLN] & 4102 & 16325 & 25557 & 28436 & 26367 & 26184 \\
\hline
\end{tabular}

Figure 9. The exemplary screenshot of spreadsheet presenting cash flow statements (source: self study)

Because the dividend discount model is recommended for bank valuation purposes both capital adequacy ratios and the dividend payout shall be additionally considered in balancing procedure.

Cash flow statement is critical for making each of the financial models. The cash flow statement records all cash inflows and outflows affecting balance sheet accounts, and determines the company's year-end cash and debt balances. Each line item on the cash flow statement should correspond to a year-to-year change in a line item on the balance sheet. The fact that every account which changes on the balance sheet is reflected on the cash flow statement is the necessary condition of the logical correctness of the financial model. Meeting this condition allows the balance sheet to balance.

The basis cash flow statement implemented in the financial model shall include three sections:

- Cash from operating activities

This is the fundamental cash flow of the business, derived from its net income corrected for non-cash income or expense items and for changes in working capital. It defines the cash available to make necessary investments and to satisfy the interest and dividend obligations of the business.
- Cash from investing activities

This reflects all of the capitalised investments of the business, in fixed assets or in intangibles. It also includes the proceeds from any sale of assets.

- Cash from financing activities

This reflects the business's decisions concerning external financing: repayment/issuing of debt. It also includes the effect of the financial revenues and financial expenses paid. The distinction and level of complexity of each of the sections shall be considered on projectby-project basis e.g. if the objective of the financial model is to assess the optimal future investment schedule than investing and financing sections of cash flow statements shall be cover in details.

The basic drivers to cash flow captions are presented in Table 4.

As presented above the majority of the cash flow captions shall derive direct from balance sheet captions. In modelling practise it is recommended to link cash flow captions direct to the balance sheet captions e.g. change in indebtedness shall be linked to changes in debt on 'Balance Sheet' spreadsheet, rather that on changes in debt balances calculated on 'Indebtedness' spreadsheet. 
llustrative Valuation of ABC Company as of 31 March 2003 / Discounted Cash Flow Approach - Free Cash Flow to Equity

\begin{tabular}{|c|c|c|c|c|c|c|c|c|c|c|}
\hline & Unit & 2004 & 2005 & 2006 & 2007 & 2008 & 2009 & 2010 & 2011 & 2012 \\
\hline \multicolumn{11}{|l|}{ Estimation of Beta for rhe equity of the company } \\
\hline Tax rate & {$[\%]$} & $8.7 \%$ & $7.6 \%$ & $7.6 \%$ & $7.6 \%$ & $7.6 \%$ & $7.6 \%$ & $7.6 \%$ & $15.2 \%$ & $15.2 \%$ \\
\hline Unlevered beta & [number] & 1.15 & 1.15 & 1.15 & 1.15 & 1.15 & 1.15 & 1.15 & 1.15 & 1.15 \\
\hline $\mathrm{D} / \mathrm{E}$ ratio for the Company & {$[\%]$} & $159.0 \%$ & $180.2 \%$ & $171.9 \%$ & $135.4 \%$ & $97.3 \%$ & $61.9 \%$ & $30.8 \%$ & $8.1 \%$ & $0.0 \%$ \\
\hline Beta levered & & 2.82 & 3.07 & 2.98 & 2.59 & 2.18 & 1.81 & 1.48 & 1.23 & 1.15 \\
\hline \multicolumn{11}{|l|}{$[$ Beta levered $=$ Unlevered Beta $x(1+(1-T) \times(D / E))]$} \\
\hline \multicolumn{11}{|l|}{ Estimation of cost of equity for the Company } \\
\hline Average risk free rate $[\mathrm{Rf}]$ & [\%] & $5.9 \%$ & $6.1 \%$ & $5.1 \%$ & $4.7 \%$ & $4.6 \%$ & $4.6 \%$ & $4.6 \%$ & $4.6 \%$ & $4.6 \%$ \\
\hline Beta (levered) & & 2.82 & 3.07 & 2.98 & 2.59 & 2.18 & 1.81 & 1.48 & 1.23 & 1.15 \\
\hline Long-term risk premium [ Rp ] & {$[\%]$} & $5.90 \%$ & $5.90 \%$ & $5.90 \%$ & $5.90 \%$ & $5.90 \%$ & $5.90 \%$ & $5.90 \%$ & $5.90 \%$ & $5.90 \%$ \\
\hline Cost of equity [Ce] & {$[\%]$} & $22.5 \%$ & $24.2 \%$ & $22.6 \%$ & $20.0 \%$ & $17.4 \%$ & $15.2 \%$ & $13.3 \%$ & $11.8 \%$ & $11.3 \%$ \\
\hline \multicolumn{11}{|l|}{$[\mathrm{Ce}=\mathrm{Rf}+$ Beta $\times \mathrm{Rp}+\mathrm{Sp}]$} \\
\hline \multicolumn{11}{|l|}{ Free cash flow to equity valuation } \\
\hline Change in excess cash & ['000 PLN] & 134 & 210 & 340 & 560 & 780 & 840 & 1023 & 1109 & 1340 \\
\hline Shange in subscribed share capital & ['000 PLN] & -47 & 0 & 0 & 0 & 0 & 0 & 0 & 0 & 0 \\
\hline Dividends & ['000 PLN] & 0 & 0 & 0 & 0 & 0 & 0 & 0 & 0 & 0 \\
\hline Free cash flow to equityholders [FCFtE) & ['000 PLN] & 87 & 210 & 340 & 560 & 780 & 840 & 1023 & 1109 & 1340 \\
\hline Cost of equity $[\mathrm{Ce}]$ & {$[\%]$} & $22.5 \%$ & $24.2 \%$ & $22.6 \%$ & $20.0 \%$ & $17.4 \%$ & $15.2 \%$ & $13.3 \%$ & $11.8 \%$ & $11.3 \%$ \\
\hline Nominal semi-year rate of return & {$[\%]$} & $10.7 \%$ & $11.4 \%$ & $10.7 \%$ & $9.5 \%$ & $8.4 \%$ & $7.3 \%$ & $6.4 \%$ & $5.7 \%$ & $5.5 \%$ \\
\hline Discount rate & {$[\%]$} & $10.7 \%$ & $23.4 \%$ & $23.4 \%$ & $21.3 \%$ & $18.7 \%$ & $16.3 \%$ & $14.2 \%$ & $12.5 \%$ & $11.6 \%$ \\
\hline Discount factor & [number] & 0.903 & 0.811 & 0.810 & 0.824 & 0.842 & 0.860 & 0.875 & 0.889 & 0.896 \\
\hline Cumulative discount factor & [number] & 0.903 & 0.732 & 0.593 & 0.489 & 0.412 & 0.354 & 0.310 & 0.276 & 0.247 \\
\hline Present value of FCFtE in period $2004-2012$ as of 31.12 .2003 & ['000 PLN] & 79 & 154 & 202 & 274 & 321 & 298 & 317 & 306 & 331 \\
\hline Assumed long-term growth rate after projeciton period & {$[\%]$} & & & & & & & & & $0.0 \%$ \\
\hline Resudual value as of 31 December 2012 & ['000 PLN] & & & & & & & & & 2228 \\
\hline Cumulative discount rate for residual rate & ['000 PLN] & & & & & & & & & 0.247 \\
\hline Net present value of FCFtE in period $2004-2012$ as of 31.12.2003 & {$[' 000 \mathrm{PLN}]$} & 2281 & & & & & & & & \\
\hline Discounted residual rate & ['000 PLN] & 3020 & & & & & & & & \\
\hline Excess assets (cash) as of 31 December 2003 & ['000 PLN] & & & & & & & & & \\
\hline Value of equity as of 31 December 2003 & ['000 PLN] & 5302 & & & & & & & & \\
\hline
\end{tabular}

Figure 10. The exemplary screenshot of spreadsheet presenting valuation results performed using FCFE approach (source: self study)

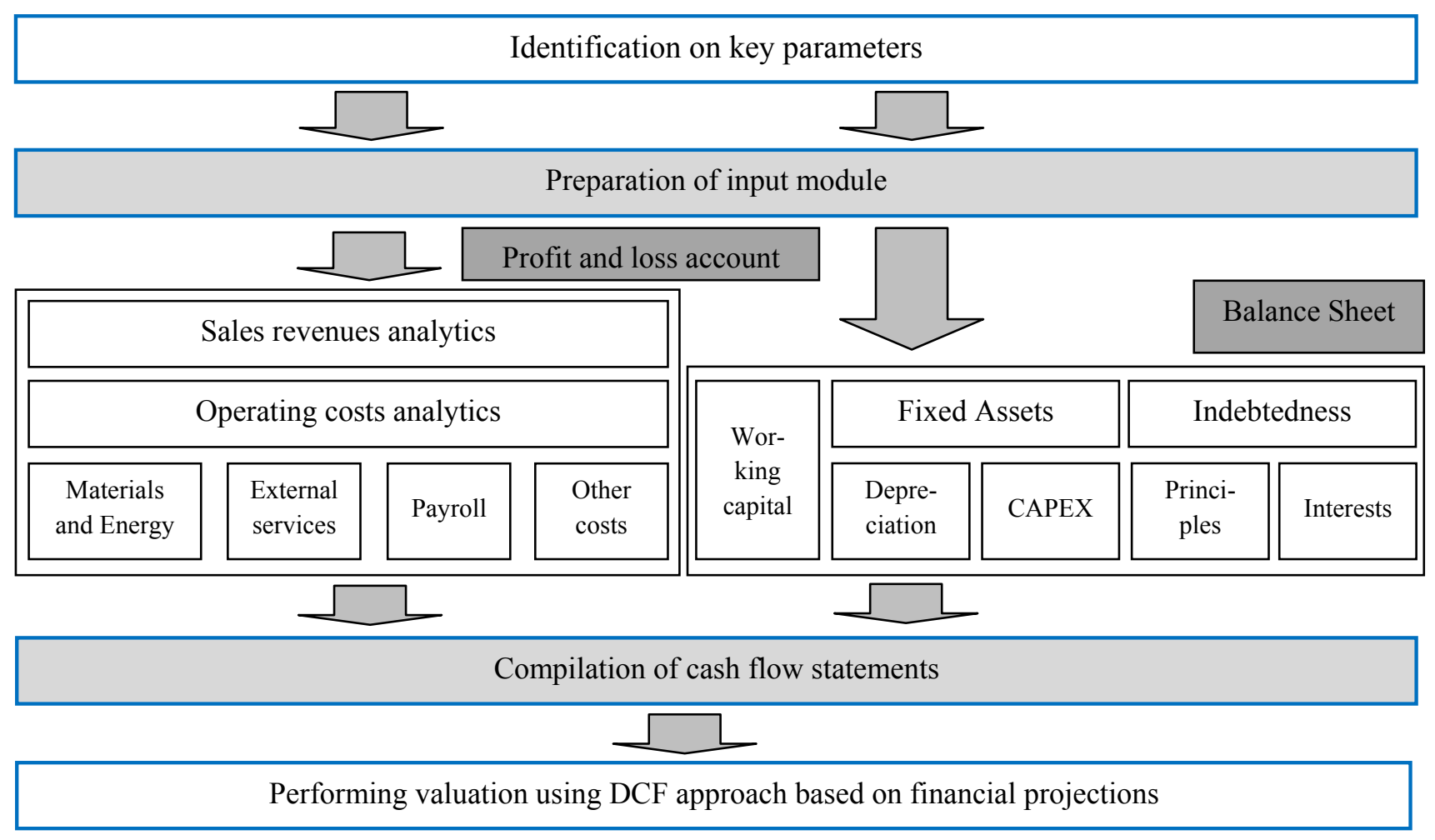

Figure 11. The major steps in building a financial model for the purpose of valuing the company (source: self study) 
This approach simplifies the control procedure, increases the transparency of the financial model and reduces the possibility of committing an error [8].

The only problem that might arise while preparing cash-flow statement is the appropriate sign of the differences between the closing and opening balances of particular assets and liabilities.

The general rules must always be applied:

- Increase in asset balances reflects cash outflow

The increase in asset balances might be perceived as a use of cash e.g. purchasing new inventory (increase in inventory balances) or allowing the clients to extend the payment period (increase in trade receivables balances). On the contrary decrease in asset balances is recorded as a source of cash e.g. selling the inventory for cash (decrease in inventory balances).

- Increase in liability balances reflects cash inflow

The increase in liability balances might be perceived as a source of cash e.g. extending the payment periods to suppliers (increase in trade payables balances). On the contrary decrease in liability balances is recorded as a use of cash e.g. repayment of debt (decrease in debt balances). The exemplary screenshot of spreadsheet presenting cash-flow statements is presented in Fig. 9.

\section{$5 \quad$ Valuation spreadsheet}

The valuation spreadsheet shall be prepared at the final stage of preparing the financial model. The major issues connected with valuation spreadsheet are presented below:

- estimation of the cost of equity/capital for the company,

- calculation of free cash flows to equity holders/firm,

- calculating the present value of free cash flow to equity holders/firm within the financial projections period and present value of residual value,

- addition and presentation of summary results $[4,2]$.

In practise, spreadsheets presenting valuation results are enclosed to the financial model at the final stage, depending on the valuation approach being used. Therefore it is possible that all three valuation results (FCFF, FCFE, DDM) are included in one financial model.
The exemplary screenshot of spreadsheet presenting valuation results performed using FCFE approach is presented in Fig. 10.

Important considerations that might be useful while preparing valuation result's spreadsheet is listed below:

- the effective tax rates and debt/equity ratios calculated on annual basis shall be applied while relevering betas,

- free cash to flow to equity shall always be adjusted for the dividends paid and increases in subscribed shareholders capital,

- the discount rate shall always be calculated on semiannual basis. Moreover, the discount factor within the first interval of financial projections shall always be calculated assuming that the cash flow occur in the middle of the interval [11, 7, 5, 10 and 9].

\section{Summary}

The major steps that shall be taken while building a financial model for the purposes of valuing the company using discounted cash flows approach are presented in Fig. 11.

The Fig. 11 presented steps are just an exemplary approach. The sequence of the steps in preparing a financial model depends in greatest part on the project specific issues and availability of input data.

Generally constructing down to the operating income line is usually the first and most important step in the construction of the model.

Most of the items in the cash flow and balance sheet are derived from the income statement. The main exceptions are depreciation, an element of cost and cash flow that is generally calculated separately on a fixed asset schedule, and net interest, derived from balance sheet information.

In summary the process of constructing financial models is long and requires to respect procedures that helps to build it in the most efficient and reliable way.

Additionally the purpose of the financial projections clearly indicates the way how the model should be constructed. 
[1] Choudhry M. - Capital market instruments: analysis and valuation. Pearson Education, Financial Times Prentice Hall, London 2002.

[2] Copeland T., Koller T., Murrin J. - Valuation. Measuring and Managing the Value of Companies. John Wiley \& Sons, New York 2000.

[3] Damodaran A. - Damodaran on Valuation: Security Analysis for Investment and Corporate Finance. Wiley Finance, 2006.

[4] Damodaran A. - Investment valuation. Tools and Techniques for Determining the Value of Any Asset. Sec. Ed., John Wiley \& Sons, Inc., New York 2002.

[5] Fabozzi F.J. - Valuation, financial modeling, and quantitative tools. Handbook of finance, Vol. 3. John Wiley \& Sons, Hoboken 2008.

[6] Fletcher S., Gardner C. - Financial modelling in Python. John Wiley \& Sons, Chichester 2009.

[7] Gioulekas S.I. - Examining corporate financing: an analysis of aggregate private equity activity, LBO valuation dynamics, and the banklending channel of monetary policy transmission. University of St. Gallen, Bamberg 2010.

[8] Ho Thomas S.Y., Sang Bin Lee - The Oxford guide to financial modeling: applications for capital markets, corporate finance, risk management, and financial institutions. Oxford Univ. Press, Oxford 2004.
[9] McCahery J.A., Renneboog L. - Venture Capital Contracting and the Valuation of High-technology Firms. Oxford University Press, New York 2003.

[10] Mercer C.Z., Harms T.W. - Business valuation: an integrated theory. John Wiley \& Sons, Hoboken 2008.

[11] McCahery J.A., Renneboog L. - Venture Capital Contracting and the Valuation of High-technology Firms. Oxford University Press, New York 2003.

[12] Olsson P.D. - Studies in company valuation. Stockholm School of Economics, Stockholm 1998.

[13] Palepu K., Healy P., Peek E. - Business analysis and valuation: text and cases. IFRS edition, SouthWestern, Australia 2010.

[14] Sardar M.N. Islam, Sethapong Watanapalachaikul Empirical finance: modelling and analysis of emerging financial and stock markets. PhysicaVerlag, Heidelberg New York 2005.

[15] Stimes P.C. - Equity valuation, risk, and investment: a practitioner's roadmap. John Wiley \& Sons, Hoboken 2008.

[16] Stowe J.D. - Equity asset valuation. John Wiley \& Sons, Hoboken 2007. 